Biografistyka Pedagogiczna

Rok 3 (2018) nr 1

ISSN 2543-6112; e-ISSN 2543-7399

DOI: $10.36578 /$ BP.2018.03.23

Ks. Edward Walewander

\title{
Ostatni Pan na Bychawie
}

[Monika Głazik, Ostatni Pan na Bychawie. Antoni Budny (1861-1943),

Wyd. Bychawskie Towarzystwo Regionalne, Bychawa 2014, ss. 272.]

\section{The Last Lord in Bychawa}

Bychawskie Towarzystwo Regionalne wydało niezwykle ciekawą książkę Moniki Głazik, zatytułowaną Ostatni Pan na Bychawie. Antoni Budny (1861-1943). Bardzo starannie i edytorsko pięknie wydana praca zasługuje na szczególne zauważenie.

Rozprawa dr Moniki Głazik mieści się w kilku zakresach badań. Można ją potraktować jako przykład badań biograficznych, a zarazem dziejów gospodarczych oraz regionalistyki. Autorka wydobywa z niepamięci i ratuje od zapomnienia wybitną postać, jaką był Antoni Budny, właściciel dóbr Bychawa-Podzamcze niedaleko Lublina, a zarazem hodowca, pozytywista. Swój majątek budował od podstaw. Wywarł też wpływ na swoich współczesnych. Jego myśl gospodarcza do dziś jest żywa wśród mieszkańców Bychawy i okolic.

Szeroko zakrojone badania podjęte przez dr Głazik są bardzo ważne, bowiem jeszcze do niedawna, niemal do końca XX w., historiografia polska stroniła od biografii. Akcentowała przede wszystkim znaczenie sił rozwojowych, determinujących życie poszczególnych społeczeństw, a tym samym

* Ks. Edward Walewander - prof. zw. dr hab., kierownik Katedry Pedagogiki Porównawczej Instytutu Pedagogiki Katolickiego Uniwersytetu Lubelskiego Jana Pawła II, edward.walewander@kul.pl. 
ich dzieje. Ówcześni naukowcy, pozostając w zgodzie z „przodującą” nauką sowiecką, twierdzili, że w aspekcie przyczyn i skutków - na tle relacji pomiędzy faktami dziejowymi, ideami oraz systemami kształtującymi życie ludzkie - człowiek jawi się wprawdzie jako indywidualność twórcza, oddziałująca na losy wspólnoty ludzkiej, lecz w ostatecznym rozrachunku dominuje cały kontekst wydarzeń. To prawda, że bez tego kontekstu trudno zrozumieć bogactwo i aktywność społeczną jednostek. Może właśnie dlatego badacze dziejów wielkich wspólnot świeckich, a często i kościelnych, z pewnym trudem akceptowali znaczenie i rolę bohatera indywidualnego, choć bynajmniej nie przechodzili obojętnie obok postaci najbardziej wiarygodnych, sztandarowych przedstawicieli danej epoki.

Prowadzone współcześnie badania biograficzne muszą nadrabiać wieloletnie zaniedbania w tej dziedzinie, powstałe w ciągu prawie pół wieku od zakończenia drugiej wojny światowej. Panował wtedy wszechwładnie antypersonalizm. Za najważniejszy twórczy czynnik historii uważano klasy społeczne, masy ludowe, a nie jednostki. Jednostka była niczym. Nic więc dziwnego, że braki i zaniedbania w biografistyce polskiej są ogromne. Zupełnie nieznane lub zafałszowane są biografie wybitnych Polaków, działających w różnych dziedzinach życia narodowego i społecznego. Poza tym w okresie PRL ze względów ideologicznych deprecjonowano zasługi ziemian polskich dla rozwoju kraju, zwłaszcza dokonane w okresie międzywojennym. Zohydzano wręcz ich działalność społeczną.

Dopiero od niedawna naukowcy za przedmiot swych badań biorą coraz częściej postacie wzorcowe, kształtujące postawy ludzi w mniejszych czy większych środowiskach, niezależnie od tego, jakiego były zawodu, stanu i jaką zajmowały pozycję społeczną. Badania prof. Albina Koprukowniaka (zm. w lipcu 2015 r.) i członków jego seminarium naukowego dowiodły, że

1 Por. takie rozprawy jak między innymi: Janusz Korga, Kazimierz Bogdan Fudakowski (1880-1965), ziemianin i działacz polityczny, Lublin 2004; Agnieszka Hucz, Dobra włodawskie i ich właściciele w latach 1837-1917, Lublin 2005. postaciami wzorcowymi było wielu ziemian ${ }^{1}$. Po kilku dziesięcioleciach zakłamania i bezpodstawnych zarzutów należy ich obecnie rehabilitować, ukazać ich zasługi i całą prawdę o nich.

Jedną z takich nieprzeciętnych postaci był Antoni Budny. Już na przełomie XIX i XX w. Henryk Wiercieński, znany regionalista i badacz dziejów gospodarczych Lubelszczyzny, pisał o jego sukcesach hodowlanych. 
Podkreślał, że dzięki takim hodowcom jak on „gubernia lubelska zajęła pod względem hodowli koni rasowych jedno z pierwszych miejsc nie tylko w kraju [tj. w Królestwie Polskim - E. W.], ale i w całym państwie [tj. na terenie cesarstwa rosyjskiego]"2.

2 H. Wiercieński, Opis staty-

Jednym z celów, jakie postawiła sobie dr Monika Głazik w recenzowanej tu pracy, jest ukazanie wkładu Antostyczny guberni lubelskiej, Warszawa 1901, s. 285. niego Budnego w upowszechnianie na wielka skalę na ziemiach polskich przed drugą wojną światową białej angielskiej rasy świń. W swoich badaniach dr Głazik oparła się na różnorodnych przekazach: źródłach archiwalnych, dokumentach urzędowych (np. Polskich Księgach Stadnych Koni Rasy Angielskiej, katalogach wystaw rolniczych), wspomnieniach rodzinnych, prasie rolniczo-hodowlanej, fachowej broszurze autorstwa Antoniego Budnego). Wykorzystała przede wszystkim bogatą literaturę przedmiotu. Przeprowadziła wywiady z ludźmi, którzy znali i pamiętają jeszcze bohatera jej pracy. Baza poznawcza rozprawy jest bardzo obszerna.

Temat swej pracy Monika Głazik sprecyzowała konkretnie i jasno. Przyjęła właściwą metodę badań. Plan pracy nie budzi żadnych zastrzeżeń.

Dzieło składa się z dziewiętnastu rozdziałów. Cztery pierwsze ukazują korzenie rodzinne Budnego. W rozdziałach następnych opisane zostały dzieje majątku Bychawa-Podzamcze: początki tej fortuny, życiorys jej nowego właściciela, uwłaszczenie chłopów, parcelacja w latach międzywojennych. Kolejne rozdziały drobiazgowo opisują stan materialny klucza bychawskiego i jego pracowników. Rozdziały od x do XV omawiają chlewnię zarodową oraz jej ocenę na wystawach trzody chlewnej, stadninę bychawską, sukcesy stajni A. Budnego na wyścigach konnych i wystawach krajowych, a także zagranicznych. Ogromnie ciekawe są rozdziały XVI i XVII, których treść stanowi działalność społeczna Antoniego Budnego.

Bychawa miała szczęście do działaczy społecznych wielkiej klasy. W tym samym czasie co Budny działał tam inny społecznik, ks. Antoni Kwiatkowski, proboszcz bychawski. Budny wspierał go zarówno finansowo, jak i organizacyjnie.

Dwa ostatnie rozdziały dysertacji (XVIII i XIX) ukazują dalsze dzieje dóbr już po śmierci A. Budnego.

W podsumowaniu trzeba mocno podkreślić, że z olbrzymiego i bardzo rozproszonego materiału źródłowego autorka wydobyła, a następnie właściwie 
uporządkowała i zanalizowała to, co jest w nim najistotniejsze dla podjętego przez nią tematu. Wyprowadziła przemyślane i uzasadnione merytorycznie wnioski.

Praca napisana jest zwięźle, logicznie, sprawnie językowo. Na szczególne podkreślenie zasługuje znakomite wyposażenie ikonograficzne. Wiele zamieszczonych w niej ilustracji to materiały unikatowe, niezwykle cenne i ciekawe. Znacząco ubogacają rozprawę.

Ukazanie się tej pracy drukiem to wydarzenie! Jest ona ważna nie tylko dla dalszych badań regionalistycznych, ale także dla historii gospodarczej. Ukazuje bowiem ziemianina-rolnika, który nadal może być wzorem zaangażowania gospodarskiego, tak bardzo potrzebnego również obecnie. Autorka podjęła próbę wyeliminowania wielu kłamstw, jakie przez pół wieku sączono społeczeństwu, by zdyskredytować w jego oczach ziemiaństwo polskie. Wydobyła to, co przetrwało w rodzinnych opowieściach, ale dotąd nie zdążono ich opowiedzieć. Wielu z nich nie można było usłyszeć. Odszukała bogatą dokumentację i zdjęcia, które nie spłonęły wraz z domami w czasie wojny. Uporządkowała je i opublikowała.

Współczesne polskie społeczeństwo tworzą w większości ludzie oduczeni myślenia w kategoriach wspólnych interesów i wspólnego dobra. Nie szanują oni państwa. Często są bardzo nieufni i mają niską samoocenę. Tak niskiej nie spotyka się prawie w żadnym kraju zachodnim. Na szczęście już coraz więcej młodych Polaków otrząsa się jednak z kłamstwa, postrzega swoją historię w perspektywie globalnej w prawdziwie etycznej proporcji.

Antoni Budny jest znakomitym przykładem obywatela, który kocha Polskę, oddany był pracy od podstaw, a przez nią służbie całemu społeczeństwu. 